UDC 616.24-002

DOI: $10.21668 /$ health.risk/2020.4.20.eng

Review

\title{
CONTEMPORARY RISK FACTORS THAT CAUSE DISSEMINATED LUNG DISEASES
}

\author{
E.A. Borodulina, E.V. Yakovleva \\ Samara State Medical University, 89 Chapaevskaya Str., Samara, 443099, Russian Federation
}

As per data provided by Rosstat, in 2018 primary morbidity with respiratory diseases amounted to 35982 per 100 thousand people; respiratory diseases account for more than $25 \%$ in the structure of overall population morbidity and they to a great extent depend on risk factors occurrence. Disseminated lung diseases are combined into one specific group among respiratory diseases as per $x$-ray evidence.

Our research goal was to review contemporary risk factors that cause disseminated lung diseases in order to apply them in diagnostics. We searched for scientific works that were relevant for our research in such databases as RSCI, CyberLeninka, Scopus, Web of Science, MedLine, and PubMed.

There are a lot of classifications for disseminated lung diseases based on morphologic substrate peculiarities, etiology and other signs; it proves the issue is truly complicated. Patients with disseminated damage to lungs have similar $x$-ray picture of the disease and results obtained via general clinical tests also have no pathognomonic peculiarities. Clinical experts usually divide disseminations into those with infectious genesis (tuberculosis, HIV-associated disseminations, and fungus diseases) and those with non-infectious genesis (tumor disseminations, interstitial lung diseases, lysosomal storage disorders, etc.). The review outlines factors that influence both occurrence and development of lung diseases accompanied with dissemination syndrome. The greatest attention is paid to socially significant diseases as risk factors that cause them can be detected by a doctor in a patient's case history and applied for differential diagnostics. It is necessary to develop relevant prevention activities aimed at reducing risks of disseminated lung diseases as they will allow preventing morbidity and mortality among patients suffering from lung disseminations caused by correctable risk factors.

Key words: lung dissemination syndrome, risk factors, interstitial lung diseases, tuberculosis, pneumonia, HIV-infection, bronchiole-alveolar cancer, amyloidosis, pneumoconiosis.

In the $21^{\text {st }}$ century respiratory diseases occupy leading rank places in morbidity structure among the RF population; mortality and disability caused by them also remain high. According to Federal State Statistic Service data in 2018 primary morbidity with respiratory diseases amounted to 35,982 cases per 100 thousand people, and respiratory diseases accounted for $25.1 \%$ in the structure of overall population morbidity ${ }^{1}$. High morbidity with respiratory diseases to a great extent depends on risk factors including lifestyle, smoking, bacterial and viral infections, concomitant diseases, exposure to adverse occupational factors, environmental factors, and ecology [1].
Disseminated lung diseases account for a great share in the structure of morbidity with respiratory diseases; they are assigned into a separate group as per their specific $\mathrm{x}$-ray picture but still differ significantly as per their etiology and treatment procedures [2, 3]. A classification suggested by M.M. Il'kovich and A.N. Kokosov is widely used in clinical practice; it is based on peculiarities of morphologic substrate which is typical for different lung disseminations. There are also etiology-based classifications. For everyday practice, we can conditionally divide diseases that involve lung dissemination syndrome into communicable (tuberculosis, HIV-associated disseminations, and fungus diseases) and non-

(C) Borodulina E.A., Yakovleva E.V., 2020

Elena A. Borodulina - Doctor of Medical Sciences, Professor, Head of the Phthisiology and Pulmonology Department (e-mail: borodulinbe@yandex.ru; tel.:+7 (917) 958-34-82; ORCID: http://orcid.org/0000-0002-3063-1538).

Elena V. Yakovleva - Registrar at the Phthisiology and Pulmonology Department (e-mail: elena130894@mail.ru; tel.: +7 (987) 950-11-89; ORCID: http://orcid.org/0000-0003-1858-5206).

${ }^{1}$ Public healthcare in Russia. 2019: statistical data collection. Moscow, Federal State Statistic Service Publ., 2019, pp. 29-31 (in Russian). 
communicable ones (tumor disseminations, interstitial lung diseases, storage disorders, etc.) $[2,3]$.

Since «the list of diseases» is rather extensive and their x-ray signs are rather common, it is vital to develop procedures that would allow reducing time required for differentiated diagnostics of disseminated lung diseases. There are various approaches to differential diagnostics optimization described in literature; they include, for example, mathematical procedures. Here we can mention that A.E. Yankovskaya, I.V. Gorbunov, and G.E. Chernogoryuk (2017) suggested developing an applied hybrid intellectual system for differential diagnostics of disseminated lung diseases that was based on fuzzy logic principles [4].

Our research goal was to review contemporary risk factors that could cause disseminated lung diseases in order to apply them in diagnostics.

The present work dwells on revising literature on the issue related to detecting risk factors causing disseminated lung diseases. When accomplishing our work, we searched for relevant literature sources published over the last 10 years in such databases as RSCI, CyberLeninka, Scopus, Web of Science, MedLine, and PubMed.

When a primary health care specialist detects dissemination in a patient, he or she should first of all exclude disseminated tuberculosis as a probable diagnosis. Initial data collection here should concentrate on estimating risks of the disease in a patient's case history, primarily, probable contacts with people who already have tuberculosis. Disseminated tuberculosis holds the second rank place as per prevalence following infiltrative one that is on the first place. At present disseminated tuberculosis accounts for $20-30 \%$ in overall morbidity with all tuberculosis types.

HIV-infection is a factor that causes growth in number of people suffering from disseminated tuberculosis, especially when it has already transformed into AIDS [5, 6]. As per data obtained via meta-analysis performed by M. Straetemans, A. Bierrenbach, and N. Nagelkerke, patients with HIV run 20 times higher risks of tuberculosis than immunecompetent people in countries with HIV prevalence exceeding $1 \%$ [6]. Diagnostics reveals HIV and tuberculosis comorbidity more and more frequently as these two diseases naturally accompany each other due to their prevalence predominantly among the same population groups [7].

Disseminated tuberculosis is the most common type that occurs in HIV-infected people; it develops more frequently in case CD4-lymphocytes content in blood goes down to 200 cells/ $\mu \mathrm{L}$ and lower [8].

Disseminated tuberculosis can develop many years after spontaneous or medicationinduced recovery from primary tuberculosis (delayed generalization) among HIVinfected people; a key component in its pathogenesis is hematogenic, lymphogenic, or lymphohematogenic spread of tuberculosis mycobacteria [9].

CT-scan allows detecting three types of acute tuberculosis dissemination at later HIV-infection stages that involve immune suppression: they are miliary, mixed (foci with different sizes, from small to large ones), and bronchial lobular caseous pneumonia. Patients with miliary (lymphohematogenic) dissemination usually have small foci $(2-4 \mathrm{~mm}$ diameter) with low and middle intensity, and CD4lymphocytes contents in blood vary within 98-40 cells $/ \mu \mathrm{L}$ range. In case dissemination is mixed (including lymphohematogenic one) a patient has foci with their diameter varying from 2 to $10 \mathrm{~mm}$ and CD4-lymphocytes contents in blood do not exceed 39-20 cells $/ \mu \mathrm{L}$. Patients who suffer from bronchial lobular caseous pneumonia have different foci but with large ones prevailing and tending to merge and create infiltrates with multiple cavities. It indicates there is combined lymphohematogenic and bronchogenic dissemination. CD4-lymohcytes contents being lower than 19 cells $/ \mu \mathrm{L}$ mean that immune control over tuberculosis inflammation development and enclosure has been lost; it results in devel- 
opment of acute disseminated and miliary tuberculosis that cause death most frequently [10].

Patients with comorbid HIV/tuberculosis are more frequently males who have promiscuous sexual relations, smoke and abuse alcohol [11]. Recently there has been a significant growth in number of HIV-infected women in their reproductive age and it leads to growing number of children borne by HIVinfected mothers. Children with HIV-infection are also a risk group as per disseminated lung diseases [12].

J.P. Aguilar, M.B. Arriaga, M.N. Rodas, and E. Martins-Netto (2019) examined risks of fatal outcomes when tuberculosis was treated. Failure in treatment was primarily due to smoking and a patient's age and not due to sex, income, education, alcohol intake, or family status. Age older than 50 was established to increase fatal outcome probability among patients with tuberculosis by 2.8 times; smoking in case history, by 2.1 times [13]. Other authors considered smoking, alcohol abuse, as well as pancreatic diabetes and low body mass index to be the most significant individual risk factors that caused tuberculosis; their combination was assumed to result in 3-4 times higher risks of active tuberculosis [14].

Pneumocytic pneumonia has become the most common opportunistic HIV-related diseases in many countries since the first HIVinfection cases were registered. Its x-ray picture is quite similar to that of bilateral interstitial pneumonia or bilateral microfocal pneumonia; the disease develops in most patients in case CD4-lymphocytes content in blood is lower than 100 cells $/ \mu \mathrm{L}$; in rare cases it can occur even when it is more than 200 cells $/ \mu \mathrm{L}$ [15-17]. Pneumonia pathogenesis includes three stages:

1) cysts and trophozoides attaching to type I alveolocytes;

2) alveolar epithelium desquamation and cysts growing bigger inside alveolar macrophages;

3) reactive alveolitis combined with clinical symptoms with respiratory failure signs.
The disease is diagnosed basing on detected etiological factor, namely pneumocystis jirovecii, but not all regions in the country are capable of performing such examinations [15].

Morbidity with bacterial pneumonias is 5-10 times higher among HIV-infected people than among population in general. Drug intake, smoking, HIV-associated immune suppression, cirrhosis, and absence or a break in anti-viral therapy are significant risk factors that can cause community-acquired pneumonia [18]. Clinical picture of bacterial pneumonia in a HIV-infected patient does not differ from that in a non-infected one; however, the disease develops more rapidly among HIV-infected patients, bacteremia occurs more frequently, and respiratory failure is also more common among them [19].

Social burdens such as low incomes, being homeless, unemployment, staying in a penal institution, or ecologically adverse living conditions are undoubted risk factors causing both tuberculosis and pneumonia [1, 20, 21].

Non-communicable disseminated lung diseases include tumor disseminations (bronchial alveolar cancer, metastatic tumors, lymphogioleiomyomatosis), interstitial lung diseases (alveolitis, granulematosis, systemic vasculitis with damage to lungs), and storage diseases (bronchopulmonary amyloidosis, alveolar microlithiasis, etc) [2, 3].

Bronchial alveolar cancer (BAC) as disseminated lung tumor is a variety of lung adenocarcinoma that spreads along interalveolar septa without any signs of vascular, pleural, or stromal invasion. A tumor doesn't create its own stroma and uses alveolar septa instead. BAC occurs out of bronchial and alveolar epithelium cells that underwent mucinous metaplasia (chalice cells) and type II pneumocytes [22]. Smoking and type 1 human T-cell leukemia virus (HTLV-I) are considered to be risk factors that can cause BAC [23, 24]. Smoking can be considered a significant risk factor common for multiple lung diseases, both non-communicable (BAC, for example) and communicable ones 
(tuberculosis) since tobacco smoke changes susceptibility of respiratory mucosa $[13,14$, 25]. Common risk factors make differential diagnostics of disseminated diseases even more difficult.

Interstitial lung diseases are a heterogeneous group that includes variable diseases and pathologic states characterized with different parenchymatous non-infectious inflammation (as per alveolitis and/or granulematosis type) with the following fibrosis development. Conventionally experts distinguish interstitial lung diseases with unknown etiology (idiopathic lung fibrosis, other idiopathic interstitial pneumonias, lung vasculitis, eosinophilic pneumonia, etc.) and with known etiology (diffuse diseases of the connective tissue with damage to lungs, exogenous allergic alveolitis, medicationinduced damage, pneumoconiosis, etc.) [3]. Risk factors are individual for each nosology that has known etiology, for example, long-term and intense contacts with an allergen as a risk factor causing exogenous allergic alveolitis («farmer's kung», «cheese-maker's lung»); amiodarone intake («amiodarone lung») [3, 26, 27]. Longterm contacts with high-fibrogenic industrial aerosols or fine-dispersed welding aerosols result in high occupational risks of pneumoconiosis [28, 29].

Bronchopulmonary amyloidosis is the most frequent among storage diseases. Etiology of primary amyloidosis is still unclear. There are three types of the disease, idiopathic, hereditary, and senile one. Pathogenesis is related to elevated secretion of immunoglobulin and amyloid fibrils that get bonded to proteins in blood serum, absorbed with macrophages, and deposit in organs and tissues as amyloid $[29,30]$. Secondary amyloidosis usually involves amyloid fibrils that contain so called amyloid protein (amyloid A-protein). Risk factors that can cause secondary amyloidosis include chronic purulent-destructive processes (multiple bronchiectasis osteomyelitis), rheu- matic diseases, and chronic diseases in the intestines (non-specific ulcerative colitis and Crohn's disease) [31, 32].

Therefore, despite multiple research works performed all over the world, comprehensive studies that focus on disseminated lung diseases remain vital. Patients with disseminated damage to their lungs tend to have similar x-ray picture of a disease and common clinical analyses also do not have any pathognomic peculiarities. Biopsy is a truly reliable procedure for lung dissemination verification as it allows determining what lung structures and to what extent are involved into processes that are shown as dissemination on an x-ray picture.

Lung disseminations have different pathogenesis; still, we can spot out risk factors that are common for communicable disseminations. They are concomitant HIV-infection, smoking, alcohol abuse, staying in a penal institution, low income, and adverse ecological situation. Certain risk factors can be revealed by physician even at the $1^{\text {st }}$ meeting and used to perform differential diagnostics of communicable and non-communicable lung disseminations. Such factors are usually among those related to a patient's case history and include his or her lifestyle, bad habits, occupational or communal contacts with dusts and allergens, and medications he or she is taking at the moment (corrigible risk factors) as well as concomitant diseases and hereditary predisposition (incorrigible risk factors).

Development of preventive activities aimed at reducing risks of disseminated lung diseases will allow preventing morbidity and mortality among patients with lung disseminations caused by corrigible risk factors.

Funding. The research was not granted any sponsor support.

Conflict of interests. The authors declare there is no any conflict of interests. 


\section{References}

1. Sazonova O.V., Isakova O.N., Sukhacheva I.F., Komarova M.V. Habitat and incidence of respiratory organs diseases in the Samara population. Gigiena i sanitariya, 2014, vol. 93, no. 4, pp. 33-36 (in Russian).

2. Wallis A., Spinks K. The diagnosis and management of interstitial lung diseases. BMJ, 2015, vol. 7, pp. 70-72. DOI: $10.1136 /$ bmj.h2072

3. Il'kovich M.M., Novikova L.N., Il'kovich Yu.M. Discrepancies in Understanding Interstitial Lung Disease. Doctor.Ru, 2013, vol. 86, no. 8, pp. 41-45 (in Russian).

4. Yankovskaya A.E., Gorbunov I.V., Chernogoryuk G.E. Vliyanie sposoba vychisleniya vesovykh koeffitsientov priznakov i postroeniya bezizbytochnykh bezuslovnykh diagnosticheskikh testov dlya gibridnoi intellektual'noi sistemy differentsial'noi diagnostiki disseminirovannykh zabolevanii legkikh [Influence exerted by a procedure applied to calculate weighted coefficient of signs and building up irredundant unconditioned diagnostic tests for hybrid and intellectual system used for differential diagnostics of disseminated lung diseases]. VII Vserossiiskaya nauchno-prakticheskaya konferentsiya «Nechetkie sistemy, myagkie vychisleniya i intellektual'nye technologii». Sankt-Peterburg, 2017, vol. 2, pp. 191-200 (in Russian).

5. Zagdyn Z.M. The main risk factors and their impact on the HIV/tuberculosis epidemic. Rossiiskii mediko-biologicheskii vestnik imeni akademika I.P. Pavlova, 2019, vol. 27, no. 2, pp. 137-149 (in Russian).

6. Straetemans M., Bierrenbach A.L., Nagelkerke N., Glaziou P., van der Werf M.J. The effect of tuberculosis on mortality in HIV-positive people: meta-analysis. PLoS One, 2010, vol. 30, no. 5 (12), pp. 45-47. DOI: 10.1371/journal.pone.001524

7. Borodulina E., Vdoushkina E., In'kova A. Tuberculosis and HIV-infection. Vrach, 2020, vol. 31, no. 1, pp. 37-43 (in Russian).

8. Mishin V.Yu., Ergeshov A.E., Mishina A.V. Diagnosis and differential diagnosis of disseminated lung lesions in patients with HIV infection (review). Consilium Medicum, 2018, vol. 20, no. 3, pp. 8-13 (in Russian).

9. Cardona P.J. Pathogenesis of tuberculosis and other mycobacteriosis. Enferm. Infec. Microbiol. Clin., 2018, vol. 36, no. 1, pp. 38-46. DOI: 10.1016/j.eimc.2017.10.015

10. Amansakhedov R.B., Limarova I.V., Perfil'ev A.V., Abdullaev R.Yu., Sigaev A.T., Ergeshov A.E. Comparative analysis of the semiotics of disseminated pulmonary tuberculosis and exogenous allergic alveolitis in accordance with the data of computed tomography. Vestnik rentgenologii $i$ radiologii, 2016, vol. 97, no. 2, pp. 79-84 (in Russian).

11. Kornilov M.S., Yakovlev A.A., Pozdeeva E.S., Zhdanova S.N. Risk factors that contribute to the formation of combined forms of tuberculosis and HIV infection in Primorsky krai. Tikhookeanskii meditsinskii zhurnal, 2018, no. 3 (73), pp. 87-91 (in Russian).

12. Eremenko E.P., Borodulina E.A., Amosova E.A. VICh-infektsiya u detei kak factor riska tuberkuleza [HIV-infection in children as a tuberculosis risk factor]. Tuberkulez i bolezni legkikh, 2017, vol. 95, no. 1, pp. 18-21 (in Russian).

13. Aguilar J.P., Arriaga M.B., Rodas M.N., Martins E. Netto Smoking and pulmonary tuberculosis treatment failure: a case-control study. J. Bras. Pneumol., 2019, vol. 25, no. 45 (2), pp. 28-31. DOI: 10.1590/1806-3713/e20180359

14. Patra J., Jha P., Rehm J., Suraweera W. Tobacco smoking, alcohol drinking, diabetes, low body mass index and the risk of self-reported symptoms of active tuberculosis: individual participant data (IPD) meta-analyses of 72,684 individuals in 14 high tuberculosis burden countries. PLoS One, 2014, vol. 2, no. 9 (5), pp. 78-83. DOI: 10.1371/journal.pone.0096433

15. Borovitskii V.S. Pneumocystic pneumonia. Etiology, pathogenesis, clinic, differential diagnostics, treatment (lecture). Problemy meditsinskoi mikologii, 2012, vol. 14, no. 1, pp. 13-20 (in Russian).

16. Ermak T.N., Kravchenko A.V. Razvitie pnevmotsistoza i toksoplazmoza u bol'nykh VIChinfektsiei pri otsutstvii vyrazhennogo immunodefitsita [Pneumocystosis and toxoplasmosis occurrence in patients with HIV-infection in case there is no apparent immune deficiency]. Zhurnal infektologii, 2019, vol. 11, no. 3, pp. 30-34 (in Russian). 
17. Huang Y.S., Yang J.J., Lee N.Y., Chen G.J., Ko W.C., Sun H.Y., Hung C.C. Treatment of Pneumocystis jirovecii pneumonia in HIV-infected patients: a review. Expert. Rev. Anti. Infect. Ther., 2017, vol. 15, no. 9, pp. 873-892. DOI: 10.1080/14787210.2017.1364991

18. Zimina V.N., Astaf'ev A.V. Community-acquired pneumonia in adult HIV-infected patients: course, treatment, and prevention. Pul'monologiya, 2016, vol. 26, no. 4, pp. $488-497$ (in Russian).

19. Bozoyan A.A., Puzyreva L.V. Features of bacterial pneumonia at HIV-positive people. Krymskii terapevticheskii zhurnal, 2019, no. 2, pp. 28-32 (in Russian).

20. Cui Z., Lin M., Nie S., Lan R. Risk factors associated with Tuberculosis among people living with HIV/AIDS: A pair-matched case-control study in Guangxi, China. PLoS One, 2017, vol. 12, no. 3, pp. 36-39. DOI: 10.1371/journal.pone.0173976

21. Silva D.R., Muñoz-Torrico M., Duarte R., Galvão T., Bonini E.H., Arbex F.F., Arbex M.A., Augusto V.M., Rabahi M.F., Mello F.C. Risk factors for tuberculosis: diabetes, smoking, alcohol use, and the use of other drugs. J. Bras. Pneumol., 2018, vol. 44, no. 2, pp. 145-152. DOI: 10.1590/s180637562017000000443

22. Urazovskii N.Yu., Aver'yanov A.V., Lesnyak V.N. Problems of differential diagnosis of bronchioloalveolar carcinoma. Klinicheskaya praktika, 2013, vol. 15, no. 3, pp. 61-72 (in Russian).

23. Boffetta P., Jayaprakash V., Yang P., Asomaning K., Muscat J.E., Schwartz A.G., Zhang Z.F., Le Marchand L. [et al.]. Tobacco smoking as a risk factor of bronchioloalveolar carcinoma of the lung: pooled analysis of seven case-control studies in the International Lung Cancer Consortium (ILCCO). Cancer Causes. Control., 2011, vol. 22, no. 1, pp. 73-79. DOI: 10.1007/s10552-010-9676-5

24. Nomori H., Mori T., Iyama K., Okamoto T., Kamakura M. Risk of bronchioloalveolarcarcinoma in patients with humanT-cell lymphotropicvirus type 1 (HTLV-I): case-control study results. Ann. Thorac. Cardiovasc. Surg., 2011, vol. 17, no. 1, pp. 19-23. DOI: 10.5761/atcs.oa.09.01529

25. O'Leary S.M., Coleman M.M., Chew W.M. Cigarette smoking impairs human pulmonary immunity to mycobacterium tuberculosis. Amer. J. Respir. Crit Care Med, 2014, vol. 190, no. 12, pp. 1430-1436. DOI: $10.1164 / \mathrm{rccm} .201407-1385 \mathrm{OC}$

26. Kosarev V., Babanov S. Exogenous allergic alveolitis. Vrach, 2013, no. 2, pp. 2-6 (in Russian).

27. Cormier Y. Hypersensitivity pneumonitis (extrinsic allergic alveolitis): Canadian historical perspective. Can. Respir. J., 2014, vol. 21, no. 5, pp. 277-286. DOI: 10.1155/2014/128940

28. Babanov S.A., Budash D.S. Occupational lung diseases: statistical indicators, risk assessment and biological markers. Meditsina neotlozhnykh sostoyanii, 2018, vol. 88, no. 1, pp. 142-150 (in Russian).

29. Shi P., Xing X., Xi S., Jing H., Yuan J., Fu Z., Zhao H. Trends in global, regional and national incidence of pneumoconiosis caused by different aetiologies: an analysis from the Global Burden of Disease Study 2017. Occup. Environ. Med., 2020, vol. 77, no. 6, pp. 407-414. DOI: 10.1136/oemed-2019-106321

30. Gomzikova E.A., Samsonova M.V., Chernyaev A.L., Kurkov A.V. Pulmonary amyloidosis: basis of diagnosis. Prakticheskaya pul'monologiya, 2017, no. 3, pp. 90-97 (in Russian).

31. Khoor A., Colby T.V. Amyloidosis of the Lung. Arch. Pathol. Lab. Med., 2017, vol. 141, no. 2, pp. 247-254. DOI: 10.5858/arpa.2016-0102-RA

32. Povzun A.S., Shchemeleva E.V., Povzun S.A., Safoev M.I. Problemy diagnostiki vtorichnogo amiloidoza pri revmaticheskikh zabolevaniyakh [Issues related to secondary amyloidosis diagnostics in patients with rheumatic diseases]. Skoraya meditsinskaya pomoshch', 2014, vol. 15, no. 3, pp. 47-51 (in Russian).

Borodulina E.A., Yakovleva E.V. Contemporary risk factors that cause disseminated lung diseases. Health Risk Analysis, 2020, no. 4, pp. 179-184. DOI: 10.21668/health.risk/2020.4.20.eng

Received: 06.05.2020

Accepted: 11.11 .2020

Published: 30.12 .2020 